\title{
Munificent, Wise and Thoughtful Gifts: Grace and Peter Redpath and the Redpath Tracts
}

\section{by Allan Bell}

Shortly after Peter Redpath's election to the Board of Governors in 1864, he began to donate books to the University of McGill College. With these early donations, the Redpath Historical Collection was formed. One of the major facets of the Historical Collection are the Redpath Tracts, the first Series of which was donated by Peter Redpath in 1880. His wife, Grace Redpath, augmented the original donation in 1901 and 1903, and further additions have been made by the McGill University Lihraries. This paper presents brief hiographies of Grace and Peter Redpath and describes the history of the Redpath Tracts. What would otherwise he merely a history of a collection of tracts is enlivened by the human stories of the Redpaths, their associates, an the librarians caring for the collection.

Peu après que Peter Redpath eur été élu membre du Conseil des gouverneurs en 1864, il commença à faire don d'ouvrages à l'Université de McGill College, lesquels furent à l'origine de la Collection Redpath. L'un des principaux éléments de cette collection est constitué par les Tracts Redpath, dont la première série fut un don de. Peter Redpath en 1880. Cette collection initiale fut enrichie ensuite par les dons de son épouse Grace Redpath en 1901 et 1903, puis par d'autres en provenance des bibliothèques universitaires de McGill. Cet article présente une brève biographie de Grace et de Peter Redpath et relate l'historique des Tracts Redpath. C'est ainsi que la simple narration des faits concernant une collection d'opuscules se transforme en un récit fascinant grâce à la dimension humaine donnée aux Redpath, à leurs associès et aux bibliothécaires chargés de la collection.

I n Redpath: The History of a Sugar House, Richard Feltoe describes the establishment of Peter Redpath's association with the University of McGill College:

Elsewhere during the year [1864], Peter Redpath was honored by his election to the Board of Governors for McGill University, establishing a connection that was to last until Peter's death, and that would greatly benefit the university.'

The author is primarily concerned with the history of Redpath Sugars, and understates the influence of this beneficiary of McGill. Peter Redpath must be considered one of the greatest benefactors of McGill University, and is certainly one of the most prominent during Sir William Dawson's tenure as Principal (1855-1893). In addition to the endowment of a chair of Natural Philosophy in 1871, the establishment of the Redpath Museum in 1880 and the Redpath Library in 1893 - gifts which "ensure that the name of $\mathrm{Mr}$. Peter Redpath will ever be remembered" 2 - he also gave the University a considerable number of books.
The Museum and the Library, because of their size and tangible nature, have often overshadowed the seemingly less important gifts of books. However, by the sheer number of books donated, and the historical importance of many of these works, Redpath's influence on the scholarship of the students and faculty of McGill is as significant as the donation of the buildings which bear his name. ${ }^{3}$ By the time of his death, in 1894, the Peter Redpath Historical Collecrion had grown to more than 2676 volumes. ${ }^{4}$ Sadly, however, Redpath's philanthropic spirit proved, and in the case of the Redpath Tracts still proves, to be somewhat overwhelming. The exact number of volumes in the Redpath Historical Collection is too often clouded by the phrase "with subsequent additions" io determine the full extent of the man's contributions accurately.

\section{GRACE AND PETER REDPATH}

Peter Redpath ${ }^{5}$ was born in Montreal on August 1, 1821. He was the second child and first son of John Redpath and Janet McPhee. John Redpath emigrated from Scotland in 1816, and through his business 
ventures in the colony, first as a contractor for such projects as the Lachine Canal, Notre Dame Church, and the Rideau Canal, gained prominence and wealth. Little biographical data is available for Janet McPhee, other than that she was from Glengarry County, Upper Canada. ${ }^{6}$

Peter was educated at St. Paul's School, Montreal, which Sir William Dawson described as "then one of the best institutions of higher education in his native Province." Peter was reportedly "one of the best pupils of a large class, and ... earned the respect and love of his class-mates by his equitable and amiable temper and his kindness to the junior boys." Although these words of praise must be placed in the context of Sir Dawson's commemoration of Redpath's life, the documents available in the McGill University Archives suggest that these qualities, instilled in the young Redpath, survived until his death.

At the age of sixteen, Redpath was sent to boarding school in Manchester, England. Feltoe suggests that the move to England was a result of his father's recognition "that this [1837] was not the time to keep his family in Montreal, where martial law was in force, $" 8$ as a result of the Patriotes rebellion. The young man might well have been sent to England in any case, not only to further his liberal education but also to begin training for business, as such opportunities were more developed there.

On October 16, 1847, Peter Redpath married Grace Wood", the daughter of a William Wood of Bowden, England. Wood was "noted among his fellow citizens as an eminent promoter of philanthropic objects." 10 John Redpath's business interests led him to open the John Redpath Canada Sugar Refinery on August 12,1854, a business that he operated alone for two years and in " 1857,1858 and 1859 in company with his eldest son Peter Redpath under the firm of John Redpath and Son." Despite various set-backs, such as unfair tariff structures, the lack of locally available raw sugar and a small local market, the Canada Sugar Refinery, and its various successors, were - and indeed remain - a success.

From these beginnings, Peter Redpath's business interests took on an ever widening sphere. In 1866 he became a director of the Bank of Montreal, and soon afterwards of the Montreal Rolling Mills, Montreal Telegraph Company, several mining companies, and the Intercolonial Coal Company. In short, Redpath was involved in a wide range of Canadian business concerns. He took special interest in the development of the North-West territories, and his Directorship of the Bank of Montreal embroiled him in the political wrangling over the establishment of the Canadian Pacific Railway.

In 1879, he resigned most of his directorates and settled with Mrs. Redpath in England. They purchased Chistlehurst Manor in Kent and, with the exception of several visits to Canada, spent the remainder of their lives in England. After 1882 Redpath further limited his business activities, remaining only on the London Board of the Bank of Montreal. However, as Dawson comments, "Mr. Redpath's life in England was not altogether one of repose." ${ }^{2}$ At the age of sixty he began the reading of law, and succeeded in being called to the bar as a member of the Middle Temple of London. The fact that Redpath began a new career so late in life may be significant. Also of potential interest is the 1872 partnership agreement between Peter Redpath and his brother-in-law George Alexander Drummond concerning the Redpath Sugar Company Incorporated. The clause stating that "It is probable that Peter Redpath will be absent the greater part of the time" 13 and the fact that Redpath indeed proved to be "scrupulously absent" 14 leads Feltoe to suggest:

...perhaps it was not that Peter did not care to work, as might be supposed from his travels following his father's death [5 March 1869] but rather that hc... merely needed to find his own place in life free from the dominating influence of John Redpath. ${ }^{15}$

In his relations with McGill, however, no such qualifications exist: "In his connection with the University...Mr. Redpath was invaluable." ${ }^{16}$ Redpath took a keen interest in the University, and regularly corresponded with the Principal and other officials. In a letter dated April 26, 1888, Redpath acted on 
behalf of the University regarding a missing book with Robert Bowes, of McMillan and Bowes, Cambridge. He further offers his opinion on coeducation, saying "I do not like the idea." Also in this letter he hints at the gift he planned, remarking that "The Library must be very crowded now."17 In short. Redpath was greatly concerned with the advancement and the activities of the University, and "in the midst of many other avocations, he was always alive to its interests, and was constantly contributing to its advancement in many quiet and thoughtful ways" ${ }^{8}$ In addition to his advice and other activities as a Governor and friend of the University, the tangible and physical contributions of buildings, departmental chairs, and books make his association invaluable indeed.

Shortly after Redpath's return to England following the opening of the Redpath Library in October 1893, he died at the Manor House on the first of February, 1894. As Dawson notes the "news of his sudden and unexpected death, received by cable, fell like a thunder-clap on his many friends. " 19

Although neglected by traditional histories, Grace Redpath carried on her husband's philanthropic association with the University of McGill College. As Dawson notes:

Mrs. Redpath survives her husband, and is his executrix, not merely in the legal sense, but as one wisely and loyally desirous to carry out his wishes, and herself deeply interested in the educational and benevolent enterprises of her deceased husband." 20

Little is known of her life, other than that she was born at Bowden, Cheshire, England, ${ }^{21}$ perhaps in $1815,{ }^{22}$ and died the 29th of January 1907.

The record of her association with McGill after the death of her husband, however, can be partially reconstructed from a small collection of her letters in the University Archives. In addition to contributing two large stained glass windows to the Library, Mrs. Redpath corresponded directly with Charles $\mathrm{H}$. Gould, the first University Librarian. ${ }^{23}$ She had a keen interest in the welfare of the Library, arguably as keen as her late husband's. In an undated letter from 1894 she writes Gould about a donation of books:

I enjoyed looking at them before I sent them to Cambridge to be packed, with the others. iv y dear husband has had them for some time, he told me he would not send them untill [sic] there was a change in the Tariff, immediately on hearing that books were to be free of duty, sent them away. ${ }^{24}$

Unfortunately for this study, Charles H. Gowid and Mrs. Redpath became friends; thus their correspondence after 1895 did not regularly find its way into the University Archives. However, a misunderstanding between Dawson and Mrs. Redpath concerning the increase of her gift to the Library required official correspondence. As recorded in the Library Letter Book, when Sir William Lawson implied that she wished to increase her contribution by $\$ 10,000$ rather than to that amount, Gould was obliged to clear up the matter. After reassuring Mrs. Redpath, Gould closes the letter: "I shall try to write soon, and give you any news that $I$ can. This note is only for the business [relations intact]." ${ }^{2 S}$ Clearly the two corresponded privately, and Gould visited Mrs. Redpath when in England. Her contributions to McGill, whether motivated by fastidious compliance with her late husband's wishes, or by her own philanthropic interests, or some combination of both, were significant and considerable. Mrs. Redpath,

who from the day when she came as a young bride to Canada to the present moment has been a steadfast friend of every good work in Montreal, has, like her former partner in life, taken an especial interest in the cause of higher education, and both before and since her husband's death, has given largely to McGill University. In 1894 she contributed $\$ 11,500$ for museum expenses; in the same year she contributed $\$ 40,500$ for the maintenance of the library; and only recently she has completed the building of an additional wing to the Redpath Library. ${ }^{26}$ 
After her death, in a letter to McMillan and Bowes, the English bookdealers, Gould recognised the loss to the University, the Library and himself personally. After the typescript portion of the letter, concerning business matters, he was moved to add the following in his own hand:

The loss of Mrs. Redpath has been indeed a sad blow to the Library, and I feel personally that I have lost one of my kindest and most thoughtful friends.

Will you let me know please, how much money would be needed to keep up and bind all the continuations you have been in the habit of sending the Library for Mrs. Redpath. If I can get somebody here to supply it I shall be glad to ask you to keep on sending them to the Library. ${ }^{27}$

Although it is often difficult to intermingle personal friendship and the relationship between a benefactor and recepient, there is no evidence to suggest that Gould was not completely sincere in this sentiment. Mrs. Redpath, like her husband, had become a generous friend to McGill, always concerned with the growth and direction of the University. Together, the Redpaths were highly significant forces in the development of McGill University.

\section{THE REDPATH TRACTS: THE HISTORY}

In the McGill University Libraries' Department of Rare Books and Special Collections' Inventory of Special Collections, the Redpath Tracts are described as being

Donated to McGill in 1888, 1901 and 1903 by Mrs. Peter Redpath. They had been collected for the Redpath family in Britain by a librarian. Additions have been made since. ${ }^{29}$

The confusion about the Redpath Tracts is clearly demonstrated in this erroneous description. In fact, Series 1, the "1888" donation, was made in 1880 , and it was given by $M r$. Peter Redpath. Series 2 and
3, the 1901 and 1903 donations, were given by Mrs. Redpath; however, they were not collected by a librarian.

The fact that the Tracts are so little understood and used is largely attributable to the insufficient bibliographical control of these materials. Although the collection is referred to as one of the assets of the McGill University Libraries, ${ }^{29}$ its full extent has not been established because it has not been adequately catalogued. Had the collection been catalogued in any year previous to the beginning of Pollard and Redgrave or $\mathrm{Wing}^{30}$, the standard collection of Seventeenth Century British material might well have been the Redpath Tracts. There exists such richness and duplication in the collection that McGill could have taken the lead in the bibliographical identification of Seventeenth Century books. Instead the access to the collection was and is based on, as shall be shown, two faulty printed catalogues and a card catalogue solely dependent on the first editions of Pollard and Redgrave and Wing.

Although this paper answers a number of questions concerning the Redpath Tracts, the history of the collection remains incomplete. Given the origin of the Tracts, more information may be available in the United Kingdom. Most of the information for this paper was gleaned from the McGill University Archives and the collective memories of a number of Library staff, both past and present. This paper, then, is the beginning of the narrative of the Redpath Tracts, as told in the words of the parties concerned from archival records.

If, as according to Gerhard R. Lomer, University Librarian from 1920-1947, the "first selections" for Series One were made by the late Professor Henry Morley, ${ }^{31}$ a finer judge of English books could scarcely be inagined. Morley was an indefatigable populariser of English Literature and the "first Englishman to make the academic teaching of English his full-time profession." 32

Morley ${ }^{3.3}$ was born in London on September 15, 1822 and was educated in Germany and at King's College, London. In 1844 he began to practice medicine, but after four years his partner's dishonesty left him bankrupt. Morley then kept 
scriool, first in Manchester and then at Liscard, near Liverpoo!, until 185C. His experieraces in Gerrany strongly influenced his educational philosophies, but he was also an innovacor. He aboished all punishment, artempted to coster pucils" esteen for their sudtes, and - in true Victorian siyle - attempter to form the character of his students, $b y$ appealirg to higher morives. His schools and methods proved to be very uncoesstiul.

He riscoveres his skill at public spenking while running ais scros.s and the positive response to his style and thetoric led him to try his crand at journaism. $\because$ is submissions were noticed by Charles Dickens who offered Morley a position on the London staff of Housenold Worts. He also contributed to All the Year Round, and The Examiner, becoming the joint editor of the latter in 1856 and sole editor from 1859 to 1864 . His ritings were not limited to ragazine articles, but also included a number of books.

Morieys crue vocation became apparent when he was appointer evening lecturer at Kirig Collage in $185 \%$, and in 1865 he became professer of English Literature at University College, London. Morley lectures were not only heard in London; he brought his lectures to other parts of Britain, traveling especially to the north of England. As an academic, he turned his pen to the writing of text-books, notably his First Sketch of English Literature, which sold over thirty four thousand copies during his lifetime. He is principally remembered as a popularizer of the English Classics, editing multi-volume series, such as Cassell's Library of English Literature (5 volumes. 1875-81), Morley's Universal Library (63 volumes. 1883-88), Cassell's National Library (214 volumes. 1886-90), The Carisbrooke Library (14 volumes. 1889-91), and Companion Poets (9 volumes. 189192). In 1879 his labours brought him an Honourary LL.D from Edinburgh and in 1882 the principalship of University Hall, London. He retired to Carisbrooke, Isle of Wight, to complete English Writers, which, by the time of his death on May 14, 1894, remained incomplete at eleven volumes.

From the evidence of bookplates and order books, Series One of the Redpath Tracts was presented to McGill in 1880. Perhaps because of the opening of the Redpath Miuseum in the same year, the 307 volumes are not mentioned explicitly in the documents that I perused in the University Archives. Although Peter Redpath was probably thanked for surie a significant gift, a lefier of thanks, or an acknowledgement in the "Volumes of Donations to the Library," has not been located.

A year after ihe creation of the Committee of Corporation regardirg the affairs of the Library, the committee recognised and reportet a problem with the iracs in the Anmul Pepon of 1883 :

in the Redpath collection there are 307 volumes of very valuabie Tracts and Pampinieis, on political and cognate subjects, and extending from the year 1632 to 1860 , which have never been catalogueal; [sicl so that their contents are practically unknown, and their value for reference is consequertly diminished. It would, therefore, be a great boo: to students of the political history of the Wother-commity were a catalogue of these tracts and pamphlers prepared for their use. But to to this, as it should be done, would be a work involving the expenditure of much time and thought, and of more money than your commmittee can, under present circumstances, venture to apply for. ${ }^{34}$

The Committee's attitude characterises the treatment the tracts have received in the intervening one hundred years and more at McGill. While the collection is recognised as a valuable and useful research collection, the library, as we shall see, has been unable to devote the money or the thought to provide bibliographical control equal to the value of the tracts.

One year later, in the Annual Report of 1884, the oversight seems to have been addressed, and the committee proully reports:

A very important and much-needed improvement has been made by the preparation and printing, in a handsome form, of a special Catalogue of the 307 
Vol. 39. $\quad \mathbf{1} 647(2)$.

Propositions from Parliament to the King for Peace.

Ordinance. Relieving Weekly Assesments.

Ordinances. Conceraing Sequestring.

Declaration of Sir Thomas Fairfax.

Vox Militaris. Declaration of the Army.

Hugb Peters. A Word for the Armie.

A Word to Mr. Peters.

John Saltmarsh. A Letter from the Army.

David Jenkins. An Apology for the Army.

Poisonous Letters of David Jenkins Answered.

The Cordiall of Mr. David Jenkins.

Nine Queries upon the Army against the Eleven Members.

A full answer of the Eleven Members.

A Declaration of the Lord Mayor.

The Declaration of General Massey.

Declaration of Sir John Gaise, Lord Mayor.

Sixteen Propositions concerning Government of a King.

Queries concerning the Negative Oath.

The Assembly Man.

Several Speeches delivered at a Conference concerning the Power of Parliament to proceed against their King for Misgovernment.

Vor. 40. 1647 (3).

A. Religious Retreat sounded to a Religious Army.

Scruples from the Army. (A Dialogue.)

Dudley Diggs. Unlawfulness of Subjects taking Arms against their King.

Resisting the Lawful Magistrate under colour of Religion.

A Protestation of the King's Supremacie by Non-Conforming Ministers.

Account given to Parliament by Ministers sent to Oxford.

Samuel Richardson. Toleration in matters of Religion.

Vor. 41. I647 (4).

Propositions concerning Church Government. Edinb.

Queries Touching Ordination of Ministers.

A Testimony to the Truth of Jesus Christ.

Thirty two Articles from Holy Scripture.

"Vindication of Reformed Churches," by L. S.

Answer to Tract, "Vindication of Reformed Churches."

Declaration. Assembly Church of Scotland to brethren in England.

Samuel Torshel. Disposing the Bible into an Harmony.

Character tending to Love.

Samuel Kem, D.D. An Olive Branch, a Sermon.

A Sermon. King's due, People's duty.

Humfry Ellis. Two Sermons.

Figure I. Page 43 from an unannotated copy of the Catalogue for Series I. A Catalogue of Books Chiefly Relating to English and American History and Antiquities, Together with a Collection of Historical, Ecclesiastical, and Political Tracts (from 1624). Presented to the University of McGill College, Montreal, by Peter Redpath, Esq. 1864-1884. (Cambridge: MacMillan and Bowes, 1884). 
Vor. 39. I $6_{47}(2)$.

1 Propositions from Parliament to the King for Peace.

2 Ordinance. Relieving Weekly Assesments.

3 Ordinances. Concerning Sequestring. 1646.

4 Declaration of Sir Thomas Fairfax.

5 Vox Militaris. Declaration of the Army.

6 6 Hugh Peters.2 A Word for the Armie.

7 A Word to Mr. Peters. and Jies wolde fot the Porliament

8. John Saltmarsh. A Letter from the Army.

- David Jenkins. An Apology for the Army.

10 Poisonous Letters of David Jenkins Answered. I\% H.P.

11 The Cordiall of Mr. David Jenkins. - Replete M.P.

12. Nine Queries upon the Army against the Eleven Members $164 \%$

13. A full answer of the Eleven Tembers.

14. A Declaration of the Lord Mayor. and aldermen of Indos 1047

15 The Declaration of General Massey. and Clond Panr

16 Declaration of Sir John Gaise, Lord Mayor. and ohturs?

17 Sixteen Propositions concerning Government of a King.

is Queries concerning the Negative Oath.

19 The Assembly Man. Uy f.15.1647.

20 Several Speeches delivered at a Conference concerning the Power of Parliament to proceed against their King for Misgovernment.1648

Vor. 40. $\quad 1647$ (3).

I A Religious Retreat sounded to a Religious Army.

2 Scruples from the Army. (A Dialogue.)

3 Dudley Diggs. Unlawfulness of Subjects taking Arms against their King.

4 Resisting the Lawful Magistrate under colour of Religion.

5 A Protestation of the King's Supremacie by Non-Conforming Ministers.

6 Account given to Parliament by Ministers sent to Oxford.

7 Samuel Richardson. Toleration in matters of Religion.

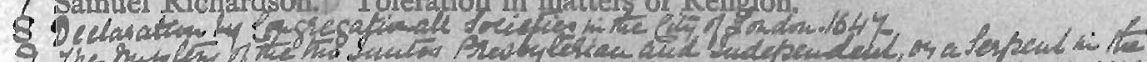

9 the mufury.

Propositions concerning Church Government. Edinb.

4 Queries Touching Ordination of Ministers.

5 A Testimony to the Truth of Jesus Christ.

6 Thirty two Articles from Holy Scripture.

7 "Vindication of Reformed Churches," by L. S. Lan arus Leaman

8 Answer to Tract, "Vindication of Reformed Churches,"

9 Declaration. Assembly Church of Scotland to brethren in England.

10 Samuel Torshel. Disposing the Bíble into an Harmony.

$1 /$ True Character tending to Love.

I'. Samuel Kem, D.D. I An Olive Branch, a Segrnon.

13 A Sermon. King's due, People's duty. In If

14 Humfry Eillis. Two Sermons.

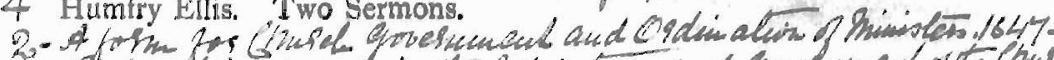

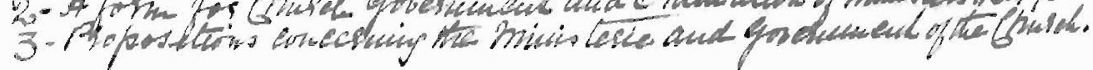

Figure 2. Page 43 from the annotated copy of the Catalogue for Series I. 
vols. of very valuable Tracts and Pamphlets in the Redpath Collection, to which reference was made in the last Annual Report. For this service the University is indebted to Mr. Peter Redpath, the Donor of the Collection, who defrayed the entire cost of the preparation and printing of the Catalogue. Much credit is also due to Mr. Taylor, the Assistant Librarian, who was charged by Mr. Redpath with the preparation of the Catalogue, for the very careful and satisfactory manner in which he did his part of this important work. ${ }^{35}$

Unfortunately, however, the Catalogue was soon found to be lacking entries for several pamphlets. There is an annotated copy, which Stuart J. Reid, who collected Series 2 and Series 3 for Mrs. Redpath, is said to have used to avoid duplication (Figures 1 and 2). To date, the best listing of the pamphlets in this and the other Series - excluding Series 3, which has brief cataloguing records on MUSE - is the card catalogue in the Department of Rare Books and Special Collections, but, as will be discussed below, its adequacy is also open to question.

Series Two, or the Grace Redpath Collection, was presented to the Library in 1901. (Figure 3) "The Report of the Library Committee", June 10 to Oct. 5, 1901, states:

One of the most important gifts of books that the Library has ever received has come from [sic] from Mrs. Peter Redpath, in the form of some 5,000 tracts, handsomely bound in about 580 volumes. These tracts have been collected for Mrs. Redpath by Mr. Stuart J. Reid, editor of the series "Prime Ministers of Queen Victoria", and author of a life of Lord John Russell, a life of Sidney Smith and other works. Mr. Reid has been actively engaged upon this task during the last five years, and the basis of the present collection is a group of state pamphlets gathered by Sir John Bramston (16111700), Chairman of the Committee in the House of Commons in the early years of Charles II's reign. The whole collection is intended to supplement the Redpath Historical Tracts given by Mr. Peter Redpath some years ago, and illustrates the growth of opinion in matters religious, political literary and social, from the days of Queen Elizabeth to the dawn of the 19 th century. ${ }^{36}$

The text of this report has been "borrowed" from Stuart J. Reid's introduction to the collection, bound in each volume and in its printed catalogue, and this description has not been substantially changed since 1901 .

Biographical data on Stuart Johnson Reid is difficult to find; however, his compilation of both Series 2 and Series 3 makes him integral to the story of the Redpath Tracts. Reid ${ }^{37}$ was born at Newcastleupon-Tyne, probably in the year 1849, and was the son of Alexander Reid, who died in 1887. He was the brother of Sir Thomas Wemyss Reid, who is listed in The Dictionary of National Biography, and the father of Thomas Wemyss Reid (born 1886).

Nothing is known of his early education. Reid was, however, a student at Cheshunt College from 1871 to 1875 and he bequeathed the College a marble bust of John Milton and one thousand volumes from his library in "acknowledgement of the reduced fees accepted by the Committee from him on account of his father's narrow means. . . when the testator was a student at the College." 38

His chosen profession was that of a minister, and it is through this occupation that he and his wife probably met the Redpaths. He was Congregational Minister at Higher Broughton, Manchester, 1875 to 1880; at Wilmslow, Cheshire, 1880 to 1887; at Chistlehurst, 1888 to $1895^{39}$, and at East Grinstead in (and around) 1905. It would seem that the Redpaths and the Reids became acquainted while Reid was at Chistlehurst. The couples appear to have become friends, and remained so even after Reid's move to East Grinstead. Grace Redpath mentions the Reids in fond terms in two letters. In a letter to Gould dated 
November 2, 1895, Mrs. Redpath states that she "has just returned from a few days visit to $\mathrm{Mr}$. \& Mrs Reid in their new home in East Grinstead, I am hoping that they will be better for the change; " in the second letter, dated January 25, 1896, she states that she has "been to see them once, \& Mrs. Reid has been here, but I do not see them as frequently as I formerly did." $\$$

Stuart J. Reid also had a great deal of interest in literary work. He is "said to have been on the staff of Cassell's the publishers," and was for "14 years the chief reviewer of the Leeds Mercury and for 30 years on the literary staff of the old Standard. "4l $\mathrm{He}$ contributed to the Spectator, Speaker, The Dictionary of Narional Biography, and other periodicals. In his own words, he wrote "constantly, \& often under [his] name and initials for the Weekly Survey". ${ }^{42} \mathrm{He}$ also had business interests, and was a director of the London publishing concerns Sampson Low and Company, and of Isbister and Company. ${ }^{43} \mathrm{Mr}$. Reid died in East Grinstead on the 27th or 28th of August, 1927.

Reid, however, was neither a librarian nor a bibliographer; ${ }^{44}$ he was probably recruited by his friend Mrs. Redpath to augment the 1880 donation of Peter Redpath because of his literary interests. The first mention of these "new Tracts" came in a Ietter dated July 29, 1895 from Reid to Gould which was written and posted to the Librarian while he was visiting Great Britain. The two had discussed the proposed Tracts, among other matters, and Reid, perhaps optimistically at this early date, is already wondering about the University die for the binding. Reid also mentions that he

shall look forwarded [sic] to the annotated copy of the Redpath History Tracts Catalogue with pencil notes showing the ommissions [sic] in the printed book. ${ }^{45}$

Although in a letter to Gould on January 251896 , Mrs. Redpath is speaking of a particular moment in time, her words probably encapsulate Reid's work for the next six years; Mr. Reid became "busy at work with some valuable Tracts he has met with." ${ }^{40}$
Gould and Reid carried on a brief and factual correspondence from September 1899 to November 1901 concerning the tracts. On September 18, 1899 , Reid requested that Gould send "a sample volume of the Peter Redpath Historical Tracts, as the time is rapidly approaching wher I hope to bind up the companion Grace Redpath Series." Mirs. Redpath and Reid wisned "to keep the [twol works as far as possible uniform."

\section{Reid continues with an apolcgy:}

I am sorry that the work has taken so long, - but there have been real difficulties in the way - tedious to relate, though none the less actuai.

I think that the new collection will be a real \& great acquisition to the Library. It certainly represents a vast amount of search \& I have taken care by an appeal to your annotater catalogue to prevent repetitions, \& to make the collection strong in years and in subjects in which its predecessor was weak.

Reid concludes the letter with an offer to Gould: "If there is any point you wish to raise with me about the books, let me hear." 47

Unfortunately, the "real difficulties," too "tedious to relate," would have been most valuable to this study. Where and how Reid bought the Tracts can only be surmised. Given his occupation and interests, it is unlikely that he went to auctions personally. He could have hired "pickers" to locate and buy the material, but his most probable course of action would have been to tell various booksellers that he was looking for this type of material. The collection was clearly expensive; Robert Bowes of McMillan and Bowes wrote Gould on November 2, 1900 that "Mrs. Redpath spoke to [Bowes] some time since about cutting down the continuations [for McGill], as she had been spending a good deal on the Historical pamphlets selected by Mr. Stuart Reid." 48

Gould, when he answered Reid on October 20, 1899, did indeed have some suggestions as to the presentation of the Tracts. After acknowledging that he had sent a Volume of the Redpath Historical 


\section{Eatalogue}

OF A COLLECTION OF

\section{亚) istorical Eractis \\ I $561-1800$}

IN DLXXXII VOLUMES

COLLECTED AND ANNOTATED BT

STUART J. REID

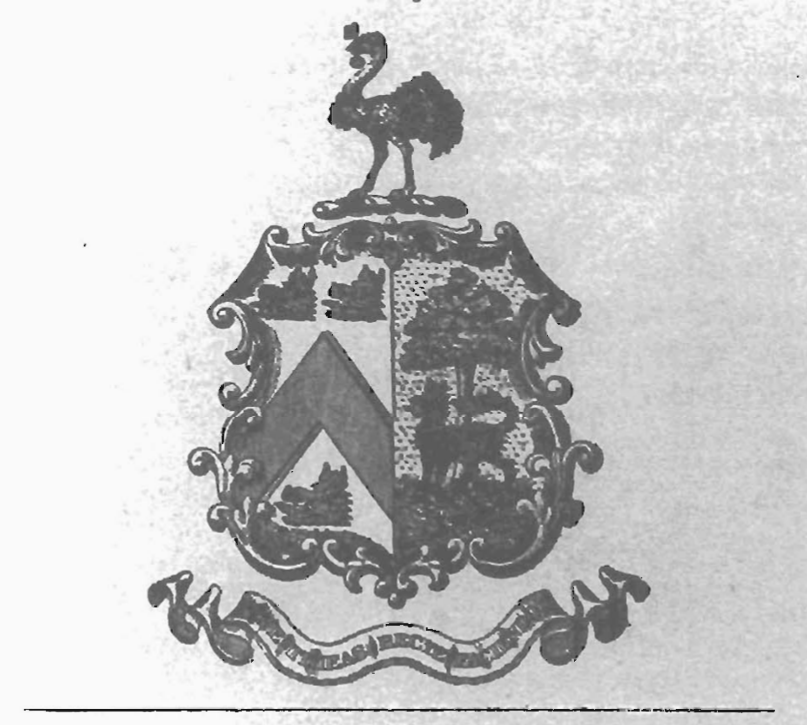

THE OIFT OF MRS. PETER REDPATH

то тне

REDPATH LIBRARY, MOGILL UNIVERSITY, MONTREAL

LONDON: PRINTED BY THE DONOR

YOR PRIVATE CIRCULATION

$\mathrm{MCMI}$

Figure 3. The title page of the Printed catalogue for Series 2. Catalogue of a Collection of Historical Tracis, 1561-1800 in DLXXXII Volumes, Collected and Annotated by Stuart J. Reid. The Gift of Mrs. Peter Redpath to the Redpath Library, McGill University, Montreal. (London: Printed by the donor for private circulation, 1901). 
Tracts, he expresses his certainty that "the new collection will be most valuable and we shall be very glad, indeed, to get it in the Library." He then offered Reid a reasonable opinion; an opinion so reasonable, in fact, that one could wish that it had been followed:

I think it would be well to bind the Tracts so far as possible in very thin volumes. It is much more convenient to catalogue them when this is done. ${ }^{49}$

Upon receiving the volume from Gould, however, Mr. Reid found himself with a problem. In his letter dated November 2, 1899 he writes

I should much prefer to have one of the Earlier volumes, say vols XIV - XV - or XVI \& anyhow not later than the middle of the seventeenth century. The Tracts you send relate to the middle of XIX Century, \& I have none anywhere near that in date. The strength of the new collection is in the seventeenth century.

In his post script he made his request more explicit: "I should like to see in the fresh volume sent how old tracts of various sizes have been treated. What I want in fact is a typical difficult small quarto volume. ${ }^{-50}$

On November 13, 1899, Gould acquiesced to Reid's request with reservations: "I cannot see, however, that [the new volume] will be of any assistance to you, as the binding of the whole series is absolutely uniform." The volume that Reid was first mailed would not differ in outward appearance from the next one sent. The difference would be the handling of different formats within one volume. As Series 1 is bound for the most part by date, octavos, quartos and even sixteenmos find themselves in the same volume. Gould remarked quite correctly "that the binding of these is by no means a model which I should wish to see followed." He continued:

In the first place, it is a great pity and, as you know, detracts seriously from the value of the pamphlets to remove the original covers before binding. In the next place, trimming of the edges is fatal, and this has been done to a surprising extent in the collection we now have. I should therefore recommend that the volumes sent you be used solely to preserve uniformity in outward appearance, and I would also recommend, as in my former letter, most strongly, that the number of pamphlets in each volume be restricted as far as possible. This will save a great deal of time and money in the cataloguing. ${ }^{51}$

Again, Gould had given sound advice, but unfortunately it was not followed. Reid did bind together different formats. Further, in volume DLXXX, the bottom three centimeters of the pages of one of the pamphlets is folded over to fit into the codex. This volume is not only cropped, as are the other volumes, but also gilded. While Reid took more pains to bind items of similar size together, he nonetheless bound and cropped the tracts of Series 2 .

Clearly, the Tracts were being bound by the end of 1899, and yet they did not arrive in Montreal until the middle of 1901. For the year and a half between these two dates, it appears that Reid decided to take on the cataloguing of the tracts himself. (Figure 4)

After the Tracts had been received by McGill, Reid wrote to Gould a significant letter dealing with the the reception of the Catalogue:

I was glad to Iearn of the safe arrival of the Tracts and Mrs. Redpath sent me Lord Strathcona's letter of thanks the other day.

I want to tell you that Mrs. Redpath denies [that] copies of the Catalogue [were] sent to the Parliament Library, Ottawa, \& also to Quebec and Toronto. I told her that you probably had sent these, but if any [sic] of the three is not on your narrow list will you kindly let me know, \& I will forward the volume with explanatory letter.

I an sure you will be pleased to learn that Sir Maunde Thompson, Sir William 
Muir (Edinburgh) Principal Donaldson (St. Andrews) Mr. Clark (Cambridge Registrar) \& others have expressed in warm and emphatic terms the sense of value of the gift. Mrs. Redpath singled out two great Nonconformist Colleges Mansfield Oxford [,] Westminster Cambridge for the gift, \& both Dr. Fairbairn \& Dr. Oswald Dykes have written in most appreciative terms. The former describes the volume as a sound $\&$ valuable bit of work $\&$ likely to prove of the utmost value to students engaged in historical research. At Cambridge they were particularly glad to get the book because they are making a collection of Tracts themselves. Maunde Thompson - 2 copies have gone to the British Museum - wants three to go to Australia, but I am not sure that they can all be spared; especially as Sir William Muir is anxious that the same number should be sent to India \& a claim has been put in for South Africa. No copies - beyond one or two reserved by Mrs. Redpath - have gone to private hands, but 2 have been sent to the press Athenaum and Litercture.

Mrs. Redpath was anxious that her life-long friend Sir Charles Tupper should at all events see the book \& in the end we arranged that he should carry out to Canada a copy to Manitoba University. Besides this a special copy has gone to Dr. McVicar at the Presbyterian College in your city at Mrs. Redpath's request. One has gone to the University of Wales \& another to that of Dublin, \& Glasgow \&Durham[added] have not been forgotten.

I thought you would like these details $\&$ if you will tell me about the reception on your side I shall be pleased. ${ }^{52}$

If Gould reported the "reception" of the Catalogue $e^{53}$ at Canadian and American institutions, his letter appears not to have survived. It seems likely, however, that the same positive review would be elicited from the institutions that were given a copy. A gift is not likely to be harshly criticised by recipients.

The copy sent to the Athencum however was objectively reviewed. The anonymous reviewer's conclusion concerning the Catalogue remains as valid today as when the review was written: "the catalogue is of little use as a work of reference." The criticisms are many, and sound:

Although the catalogue is clearly not the work of a trained bibliographer, $\mathrm{Mr}$. Reid has performed his task with zeal and industry. His nethod, however, leaves much to be desired. The books have been bound up, as a rule, according to the date of publication when this is known, but sometimes according to subject. ... For this Mr. Reid may not be responsible, but for the extraordinary omission of all publishers' or printers' imprints and of all descriptions of size he must surely be answerable. With an arrangement and ommisions [ sicl of this sort it becomes hard to use or check the catalogue. Notes to titles are appended, giving a brief biography of the author; when the name is familiar this seems superfluous, but when the name is less familiar the note is often onitted, although the 'Dictionary of National Biography' might have supplied materials. This would not matter much were it not for the fact that the only index provided is an index to these haphazard annotations. ... If a student happen to know the date of publication of the work he seeks, he may possibly find it, by looking through all the titles of tracts printed in that year; other clue to its place in the collection there is none. There is an occassional note to the number of the edition, but as the numbering of editions was not the practice of the early printers, an attempt to describe an old book in this way is wholly unscientific. Repeated reference to a work styled 
6. A Soveraigne Antidote to Prevent, Aprease, and Determine our Unnaturall and Destructive Civill Wars and Dissentions. ...

7. Two Speeches by the Earl of Holland and $M^{r} J_{0}:$ Pym, Esquire. Concerning a Petition to His Majestie for Peace. Spoken in Guild-Hall, 1o Novemb., to the Lord Mayor and Aldermen.

8. Scotland's Thanks-giving for the Returne of their Armie. . . .

9. The Kings Majesties Desires and Propositions to all his Subjects in Scotland. . . .

IO. A Famous and Joyful Victory ob-

Stratfor.. against Prince Rupert . another happy Victory by Lord Brooks. . . .

II. Newes from Yorke .... Sept. I, 1642. [A Letter from Henry Dickenson.]

I2. An Answerable Remonstrance of His Majesties Kingdomes of England, Scotland, Ireland, and the principality of Wales to the Parliament.

I3. The Appendix Containing many Particulars specified in the First Part of this Discourse. [Speeches by the Earl of Bristol.] George Digby, second Earl of Bristol (1612-1677).
Sat for Dorsetshire in the Long Parliament. Took Sat for Dorsetshire in the Long Parliament. Took
sides against Strafford, but afterwards went over to

F-irtorical EractB. 1561-1800.

the side of the Court, and was one of the chief in stigators of the scheme for the arrest of the Five Members.

I4. His Majesties Letter of Instruction directed and sent to the Judges of Assize. ...

I5. His Majesties Declaration to All $\mathrm{His}$ Loving Subjects. Of the 12 of August 1642.

I6. The Answer of both Houses of Parliament to the King's Message. Sent to His Mast Excellent Majesty, the $16^{\text {ch }}$ of March, $1641 . .$.

17. The Declaration and Petition of both Houses of Parliament. Presented to the King's Most Excellent Majesty, June 22,...

18. A Petition or Declaration, Humbly desired to be presented to the view of His most Excellent Majestie... . [The 'danger' \&ze. of the King 'deserting' Parliament.]

19. Edward Morgan, a Priest, His Letter to the Kings most excellent Majesty, and High Court of Parliament . . . who was drawne, hanged, and quartered, April 26 , $1642 . .$.

\section{VOLUME XLIV} 1642 (3)

I. A True Copy of His Majesty's Letter to the Generall Assembly of Scotland.

Figure 4. Pages $36-37$ of the Series 2 printed catalogue. 
'Wood's Athenoxon' betrays weakness. Mr. Reid has worked hard to identify the authors of anonymous tracts, and, since his experience in this line is not great, his labours are worthy of all praise, but many further identifications could be added. ${ }^{54}$

The review is clearly judicious. Although it seems very critical, the analyses are backed up with evidence and alternatives. The Bibliographic Society was begun in Great Britain just before this time; the anonymous reviewer of the Catalogue brings up points which identify hin, if not as a "trained bibliographer," as a person who at least understood some of the intricacies of Seventeenth Century books.

Perhaps ironically, the harshest criticism of the catalogue - and of Series 2 - came from McGill Professor Charles W. Colby, ${ }^{55}$ in a memorandum dated April 22, 1904:

Mr. Stuart Reid's Catalogue of the Redpath Tracts' [sic] must be called a slight and unscholarly performance. The collection itself contains a good deal that is valuable together with a good deal that is padding. But why such a catalogue should have been printed and put in circulation, one can hardly imagine. Mr. Reid gives the titles of his tracts, arranged chronologically, and fumishes various annotations which are almost wholly biographical. The work of transcription has been done either with little care or without the least knowledge of bibliographical method. No Librarian could think of taking this book as the basis for a set of catalogue cards. The annotations are even worse. With trivial exceptions they relate merely to the author or the edition. No attenipt is made to determine the authorship where the tract is anonymous or where the author's name does not occur in the Dictionary of National Biography. I should say that more than three-fourths of the tracts are quite unannotated. The notes when given, are often inaccurate oe [sic] puerile sometimes both. ... Mr Reid does not attempt to clear up difficulties but devotes long notes of the most commonplace character to celebrities like Bolingbroke, Fielding and $\mathrm{Dr}$ Johnson. A catalogue of historical tracts is destitute of value unless addressed to scholars. Such notes as $\mathrm{Mr}$ Reid supplies might be addressed more properly to schoolboys. ${ }^{56}$

In the University Archives with this memorandum is a typed transcription of "Correspondence" marked "Private," dated February 27 to April 21, 1904. The first letter is from A.E. Fairbaim, Principal of Mansfield College, Oxford to Sir William Peterson ${ }^{57}$ with Peterson's response second, a cablegram from Mrs. Redpath to Peterson next, followed by a letter from Peterson to Mrs. Redpath, another letter from Mrs. Redpath, a cablegram from Lord Strathcona, ${ }^{58}$ and a cabled reply from Peterson to Lord Strathcona. This carefully transcribed group of communications deals with the possibility of conferring an honorary degree on Stuart J. Reid. As early as 1901, Reid was dropping hints as to his suitability:

\section{Sir Charles Tupper thinks that McGill should give me the LL.D, and says Lord Strathcona ought to be approached. You [Gould] were good enough to say something of the same sort + if you can bring my claims forward directly or indirectly, I shall be inmesely obliged. s9 $^{\circ}$}

Sir William Peterson's first reaction to the proposal - "Has he no connection with any Scotch University to which it might be at least as natural for him to look as to us? ?0 $^{\circ}$ - illustrates a certain reluctance. This, coupled with the context of this transcribed correspondence and the Colby memorandum, ${ }^{61}$ makes it possible to conclude that Peterson was documenting a case against an honorarium for Reid. Strong justification would be needed given Reid's influential supporters, Mrs. Redpath and Principal Fairbairn. ${ }^{62}$

Despite these noted shortcomings - both objective and subjective - the printed catalogues (with a main entry card file) continue to be the only access to Series 1 and 2. Rosemary Haddad, the Print Curator and Assistant in the Department of Rare Books and 
Special Collections, wrote to Professor J.N. Buchanan in Cambridge that the "chronological listing for series $1-3$ is to be found with the tracts in bound volumes which you no doubt saw when you were here." This letter is dated 5 June $1970 .{ }^{63}$ Not only researchers, however, would be affected by the imperfections of the Catalogues. McGill's collection development librarians would be adversely affected by the failings as well.

No systematic collection development policy seems to have been developed for the Tracts since their arrival at McGill. This deficiency is not entirely to be disparaged, as the later additions of Series 4 to 9 include a number of "duplications" which are necessary for descriptive bibliographers. However, considering that McGill was given a collection of tracts recognised as significant, researchers would have been greatly served had the collection been enlarged systematically, rather than in such a haphazard manner. To add to the collections in the 1990s may be prohibitively expensive.

Although the numbering of the first three series is straightforward, for the later series, that order appears to be lost. The assumption has been that the numbers were based on successive acquisition. ${ }^{64}$ But series 4 was acquired in 1934, series 5,6 and 7 in 1925 , and series 8 in 1926. Perhaps the disbinding of the original volumes of Series 4 and the later additions made it comparable in size, scope and content to the original three series. Other British historical materials acquired have not been designated "Redpath Tracts." The funds used do not help either, as series 7 was not purchased with Redpath endowment funds, but with general funds. The later acquisitions were separate, not successive, and the criteria necessary to be labelled a "Redpath Tract" are unclear.

In the middle 1960s, however, the problems of access to the Redpath Tracts, appeared on the verge of resolution. Elizabeth Lewis, Head of the Rare Book Department, reported to John Archer, Director of University Libraries, on I August 1966, under the heading "Work done on the Redpath Tracts:"

Last year Mrs. Carroll and I [Mrs. Lewis] completed the chronological list on cards of all eight series of the Redpath Tracts (an estimated 25,000 items).

This summer ... a library school student, began the author listing on cards of the first bound series [Series 1]; in the first month she catalogued 650 pamphlets. She will be working for another month this summer and will presumably do a considerable number more than the first month. ${ }^{6.5}$

Later on, another Library school student worked on the Tracts. His report is dated 23 May 1968:

Series I contains 1424 tracts which fall into the Wing period, 1641-1700. All are catalogued, checked and filed with the exception of 340 folio size items. (Of these, 158 [(folios), added] are catalogued but the cards have not been checked. 182 [(folios), added] remain to be catalogued. I have checked corrected, and filed 534 items.)

Series 11. Volumes XXXVIICCXXXVIlI cover the Wing period, 1641-1700. These 201 volumes contain 1505 items. Of these, 1 have catalogued 719 items in volumes XLIX-CLXXIII. The cards are checked and filed.

Cataloguing follows the Wing ST? style with minor variations. Main entry is author, if known, otherwise short title. I estimate that see references, generally from title to author, are required for half the main entries.

Of the 1253 items 1 have handled, 18 tracts are not mentioned in the bibliographic sources that I consulted. ${ }^{60}$

What can be immediately ascertained from these reports is that the word "bibliography" is not the only word that is used in a variety of ways by a variety of people; "catalogue" here is minimal indeed, referring to copying from either the Pollard and Redgrave or Wing STC catalogues. Clearly, this is better than nothing. However, the problem inherent with relying solely on Short Title Catalogues for an entry is obvious indeed, especially as second editions with 
conspicuousily more entries have appeared for both Short Title Catalogues. The second report, asserting that eighteen of the tracts are not in any reference source, states the problem explicitly. Each new edition of the STCs will be a little more complete and give a slightly better representation of the output of English presses. But will each of the entries in the card catalogue be checked against these newer editions?

Also, the fact that the "cataloguer" of Series 1 was able to complete 650 entries in a month is troubling. Assume that she was full-time, worked eight hour days, did not work weekends, and further that she did not take a break, but worked for a full eight hours every day. The student completed one entry every 14.7 minutes. She could have done very little more than look at the tract, or even worse the Catalogue entry ${ }^{67}$, refer to the appropriate Short Title Catalogue and copy the information onto a card.

Serious problems with the card catalogue became apparent in the course of research on theWilliarn Prynne material (1600-1669) in McGill collections. For instance - considering the mere sixty-six items of Prynne's owned by McGill - one pamphlet, and one complete volume of pamphlets were not represented in the listings for Series 2. Also in Series 2, there are six supplementary volumes that have been "catalogued" on one card as "A Collection of fiftythree political and ecclesiastical Tracts." Further, in the unbound Series 4, a pamphlet that has never been recorded was located.

Granted, there are several real difficulties that the Redpath Tracts present to the would-be cataloguer. In the bound series, since they have been cropped, there is no convenient way of locating where one tract ends and the other begins. In the unbound series, the pamphlets stick together, or perhaps have been previously bound together and not subsequently separated; it is quite understandable that a pamphlet can be missed. The result is that the bibliographical control provided by the either the published or card catalogues is insufficient.

The need for a true catalogue of the tracts looked as if it would be met at the end of 1966. On December 7, 1966, the Dean of the Graduate
Faculty, Dr. Stanley Frost, wrote the following memorandum to Professor Donald Theall in the Department of English:

The University Libraries Committee agreed to request the Committee on Research for the sum of $\$ 5,000$ for two years in order to complete the cataloguing of the Redpath Library Tracts by January 1st, 1969. It was also agreed that a subsidy should be sought from the Canada Council to enable us to publish a catalogue when completed in the not too distant future.

1 have every hope, therefore, that we shall be able to achieve what should have been done long since for this valuable collection. ${ }^{68}$

This hope, as the Rare Book Librarian, Elizabeth Lewis pointed out to Archer, was optimistic given the available resources:

I believe that the cost of cataloguing is about $\$ 5.00$ per title, with an average of about 7-10 titles per day. Which means, that the cost will be between $\$ 100,000$ and $\$ 150,000$. It will take (10 titles per day) between 7 and 9 years to finish, at this rate.

Obviously the $\$ 10,000$ is unrealistic, as is the two-year limit.

Lewis" realism is further evidenced by her suggestion that "experienced cataloguers" should be found, and "when this money was used up, more would be required." Her postscript to this same memorandum is also interesting:

Assuming the Redpath Tract Collection to be worth a million dollars $(30,000$ tracts at $\$ 30.00$ each) it would seem well worth while to begin serious work to make them available. ${ }^{69}$

Archer responded to Lewis' concerns quickly, on February 6, 1967:

While I appreciate your memorandum 
of January 26th re the cataloguing of the Redpath Tracts this is not quite the nub of the matter under review.

The $\$ 5,000$ is available per year for two years for a specific purpose - to list (not to catalogue) the Tracts in the manner many of the are already listed in Wing.

If the Library cannot undertake this, or if the Library does not wish to oversee the work on this project, then the money will be offered to a department. We are not in a position to say "no" to a departmental attempt at listing. And if the cataloguing is to take seven to nine years - and I think this to be a reasonable estimate - then the Library Committee undoubtedly will opt for a bibliographical listing. After all $\$ 10,000$ is well spent if the users get seven or eight years use of the Tracts under a sufficient listing. And the cataloguing can go on at the same time or when staff is available.

We must think in terms of the work a non-professional can do. $\mathrm{I}$ am in sympathy with the immediate needs of the users and can readily differentiate between the work done for $\$ 10,000$ and the much more detailed and professional job to be done later. The former is a working tool - the latter will be a bibliographical tool. May I have your view on the $\$ 10,000$ matter. ${ }^{\circ}$

By April 1970, $\$ 1,500$ remained in the account. A person was to be found for the fall "to complete as much of the project as the funds at our disposal will permit." 71 And so the matter remains. The report of the Library Committee in 1883 , it seens, remains as applicable for the entire Redpath Tracts as it had been for Series 1 alone; a catalogue is needed, "but to do this, as it should be done, would be a work involving the expenditure of much time and thought, and of more money than your committee can, under present circumstances, venture to apply for."

One bright spot in the history of the bibliographic control of the Redpath Tracts is that the first 235 volumes of Series 3 is now available in MUSE. Between 1985 and 1987 brief records, without subject headings, were added to the Public Access Catalogue. Only Siemen's collection of scientific pamphlets (volumes 238-280, 1848-1881), and the eight tracts in volumes 236 and 237, remain uncataloged. This Series was selected because a "database" such as STC or Wing did not exist for 19th Century materials. Not surprisingly, of all the Redpath Tracts those with minimal cataloguing on MUSE get significanly more use, as patrons can access them through the Public Access Catalogue.

In the end, then, it is very difficult to evaluate the Redpath Tracts as a scholarly collection. Although the collection is valuable, the bibliographic control makes it difficult to use. Ironically, the lack of bibliographic control is both a positive and negative aspect of the collection. Bibliographers will find a degree of duplication convenient for their research; however, literary and historical researchers could have expected a richer and more complete source had the Library been able to systematically add to the collection. The Tracts probably are one of the finest records of British history outside of the British Library; but there could be - and probably are hidden jewels that have not been brought to light.

\section{THE REDPATH TRACTS: A SUMMARY DESCRIPTION}

Approximately 25,000 pamphlets and tracts illustrating the religious, political, scientific, and social history of the British Isles during the period 1561 to 1900, with emphasis on the Seventeenth Century. Divided into 9 series based on separate acquisition. Reportedly one of the finest collection of its kind outside the British Library. Representative of the collection's contents are the extensive holdings on the Popish plots in Series 5 and other series (1678-1700); the twenty volumes of marine tracts of Series 6 (1703-1862); the forty-two volumes of the Siemens collection of scientific pamphlets in Series 3 (1848-1881); and the six volumes of tracts by William Prynne in Series 2 (1629-1668) and other series. There is some Nineteenth Century North American and European material in the collection. ${ }^{72}$ 


\section{Series 1}

307 Volumes

1624-1860.

Bound chronologically

Selected by Professor Henry Morley.

Presented by Peter Redpath in 1880 .

Chronological printed list: A Catalogue of Books Chiefly Relating to English and American History and Antiquities, Together with a Collection of Historical, Ecclesiastical, and Political Tracts (from 1624). Presented to the University of Mc Gill College, Montreal, by Peter Redpath, Esq. 1864-1884. (Cambridge: MacMillan and Bowes, 1884).

Card File in Rare Book Department

\section{Series 2}

582 Volumes

$1561-1800$

Bound chronologically

Selected by Stuart J. Reid.

Presented by Grace Redpath in 1901.

Chronological printed list: Catalogue of a Collection of Historical Tracts, 1561-1800 in DLXXXII Volumes, Collected and Annotated by Stuart J. Reid. The Gift of Mrs. Peter Redpath to the Redpath Library, McGill University, Montreal. (London: Printed by the donor for private circulation, MCMl).

Card File in Rare Book Department

\section{Series 3}

280 Volumes

$1800-1900$

Bound chronologically

Selected by Stuart J. Reid.

Presented by Grace Redpath in 1903.

Chronological printed list: Catalogue of a Collection of Historical, Political, Economic and Other Tracts and Brochures, in 280 Volumes, 1800 1900, arranged by Stuart J. Reid. The Gift of Mrs. Peter Redpath to the Redpath Library, McGill University, Montreal. (London: Printed by the donor for private circulation, 1903).

Typed index by broad subject or title: Index to a Collection of Historical, Political, Economic and Other Tracts and Brochures, in Two Hundred and Eighty Volumes, 1800-1900, arranged by Stuart J. Reid. The Gifi of Mrs. Peter Redpath to the
Redpath Library, McGill University, Montreal. (London: Printed by the donor for private circulation, 1903).

Volumes 1 to 235, 1807 records, are represented on MUSE, ${ }^{73}$ without subject headings.

\section{Series 4}

103 boxes

1603-1897 (mostly XVIIl Century)

Original volumes disbound and boxed; a few bound volumes

38 Volumes of Tracts acquired from Bowes and Bowes, Cambridge in September 1934. Order 67211 , £72, charged to P.W. and J.C. Redpath endowment fund. Other material added.

Card File in Rare Book Department. Chronological arrangement. "Cards have been checked with Pollard \& Redgrave, and Wing; entries agree with the first edition of both works, and the corresponding number is cited."

\section{Series 5}

4 Volumes

1678-1700

Popish Plots

Bound, but not chronologically

4 Volumes of Tracts acquired from Henry Sothern and Company, London in September 1925. Order 25817, £ 10.0.0, charged to P.W. and J.C. Redpath endowment fund.

Chronological typed list: Mrs. Beryl M. Parker and Mrs. Caroline M. Riddel. A Catalogue of the Pamphlets Relating to the Popish Plot in the Tracts of the Redpath Library of McGill Universiry. Jan. 31. 1964. Note: this catalogue lists items in the first eight Series of the Redpath Tracts.

Card File in Rare Book Department. Chronological arrangement.

\section{Series 6}

29 Volumes

1703-1862

British Marine Tracts

Bound, but not chronologically

29 Volumes of Tracts acquired from Henry Sothern and Company, London in September 1925. Order $25815, \pm 18.18 .0$, charged to P.W. and J.C. Redpath 
endowment fund.

Card File in Rare Book Department. Chronological arrangement.

\section{Series 7}

11 Volumes

1604-1750

Theological Tracts

Bound, but not chronologically

11 Volumes of Tracts acquired from P.J. and A.E.

Dobell, London in September 1925. Order 23148, f3.10.-, charged to general funds.

Card File in Rare Book Department. Chronological arrangement. First editions of Pollard \& Redgrave, and Wing checked.

\section{Series 8}

12 Volumes

$1751-1842$

Scottish Tracts

Bound, but not chronologically

12 Volumes of Tracts acquired from Reynield Atkinson, London in April/June 1926. Order 28065, £7.0.0, charged to W.W. Redpath endowment fund. Card File in Rare Book Department. Chronological arrangement.

\section{Series 9}

Not bound

$1585-1816$

Around 400 Tracts acquired from Laurie Hill, Montreal in April-June 1966. Order 47286, $\$ 1778.00$ charged to Alice Redpath endowment tund; and $43560, \$ 1710.00$ charged to Alice Redpath endowment fund.

Card File in Rare Book Department. Arranged in two alphabetical lists as acquired.

\section{Notes}

1. Richard Feltoe, Redpath: The History of a Sugar House (Toronto: Natural History/ Natural Heritage, Redpath Sugars, 1991), 63. Henceforth cited as "Feltoe"

2. Sir. J. William Dawson, In Memoriam: Peter Redpath (Montreal: For the University, "Witness" Printing House, 1894), 7. Henceforth cited as "Dawson"

3. To illustrate this assertion, it can be noted that Edward Arber's, A Transcript of the Registers of the Company of Stationers' of London, 1554-I640 A.D. 5 vols (London : s.n., 1875-1894), which remains in the Reference Collection, was donated by Peter Redpath.

4. McGill University, Annual Calendar, 1894-95 (Montreal, 1896), 244.

5. The following sketch of Redath's life is derived from three main sources. Sir Stephen Leslie and Sir Sidney Lee, The Dictionary of National Biography, Volume XVI, (London: Oxford UP, 1959), 827-828; Richard Feltoe, Redpath: The History of a Sugar House (op. cit.); and Sir. J. William Dawson, In Menoriam: Peter Redpath (op. cit.).

6. Feltoe, 23

7. Dawson, 5-6

8. Feltoe, 34.

9. The Redpaths left no children.

10. Dawson, 7.

11. Felroe, 55.

12. Dawson, 9.

13. Ibid., 83 .

14. Ibid., 112.

15. Ibid., 124 


\section{Ibid., 7.}

17. Sir William Dawson to Peter Redpath, April 26, 1888, McGill University Archives (MUA), Principal's Papers, Sir William Dawson, Record Group 2.

\section{Dawson, 8.}

19. Ibid., 9.

20. Ibid., 7.

21. Henry James Morgan, Types of Canadian Women and of Women Who Are or Have Been Connected with Canada. Vol 1 (of 1). (Toronto: William Briggs, 1903), 279. Henceforth cited as "Morgan"

\section{Feltoe, 290}

23. See Peter F. McNally, "Scholar Librarians: Gould, Lomer and Pennington," Fontanus. 1 (1988), 96-97.

24. Grace Redpath to Charles H. Gould, 1894, MUA, Record Group 40, Libraries, Charles H. Gould - Correspondence, Container 3, R - 1894.

25. Library Letter Book, Volume 7, p. 804, Aug. 18 1903, MUA, Record Group 40, Libraries Container 57 , file 1598 . The letter is very badly faded, and 1 can not be sure of the words in brackets [ ]. Emphasis mine.

26. Morgan, 279. The addition was completed in 1900.

27. Library Letter Book, Volume 12, p. 40, March 18, 1907, MUA, Record Group 40, Libraries,

28. McGill University Libraries, Department of Rare Books and Special Collections Inventory of Special Collections, "Redpath Tracts."

29. "The Tracts were, for example referred to in Robert B. Downs' Resources of Canadian Academic and Research Libraries (Ottawa, 1967) 232, Lee Ash's Subject Collections, 6th ed. (1985) 1: 813, and Edwin E. Williams' Resources of Canadian
University Libraries (Ottawa, 1962) 29." Cited from A. J. Hobbins, "Sources for Tudor and Stuart History: The William Clarke Papers," Fontanus 1 (1988), 64. Also cited in Directory of Special Collections of Research Value in Canadian Libraries (Ottawa: National Library of Canada/ Bibliothèque nationale du Canada, 1992), 51 .

30. Alfred William Pollard and G. R. Redgrave, $A$ Short-Title Catalogue of Books Printed in England, Scotland \& Ireland and of English Books Printed Abroad 1475-1640 (London: Bibliographical Society, 1926) Henceforth cited as " $P \& R I$ "

, A Short-Title Catalogue of Books Printed in England, Scotland \& Ireland and of English Books Printed Abroad 1475-1640. 2nd ed. rev \& enlarged. W.A. Jackson, F.S. Ferguson and Katharine F. Pantzer. 3 vols. (London: Bibliographical Society, 1976-1991) Henceforth cited as " $P \& R$ 2"

Donald Goddard Wing, Short-Title Catalogue of Books Printed in England, Scotland, Ireland, Wales, and British America, and of English Books Printed in Other Countries, 1641-1700. 3 vols. (New York: Printed for the Index Society by Columbia UP., 1945-52) Henceforth cited as "Wing I"

- Short-Title Catalogue of Books Printed in England, Scotland, Ireland, Wales, and British America, and of English Books Printed in Other Countries, 1641-1700. 2nd ed., rev. and enlarged. 3 vols. (New York: Index Committee of the Modern Language Association, 1972-88) Henceforth cited as "Wing 2"

31. Gerhard Lomer, "The Development of the Redpath Library," The McGill News, 3:3 (June 1922), 4.

32. John Gross, The Rise and Fall of the Man of Letters: a Study of the Idiosyncratic and the Humane in Modern Literature (New York: MacMillan, 1969), 171.

33. The biographical information for this portrait is drawn from John Gross, The Rise and Fall of the Man of Letters: a Study of the Idiosyncratic and the Humane in Modern Literature (New York: Macmillan, 1969), Encyclopadia Brittanica, and Frederic Boase, Modern English Biography, Containing Many Thousand Concise Memoirs of 
Persons who have Died Between the Years 18511900, With an Index of the Most Interesting Matter (London: Frank Cass and Company, 1965)

34. University of McGill College, Annual Report 1883 , p. 12.

35. University of McGill College, Anmual Report 1884, p. 20. MUA, Scrapbook 1-a, p. 91.

36. Library Committee Meeting Minutes, June 10 to Oct. 5, 1901, p. 171, MUA, Record Group 40, Libraries.

37. The scant biographical information for this portrait is drawn from The Times (London) August 30, 1927, Who Was Who in Literature, and from information very kindly provided by The Reverend W. J. Houston, M.A., D.Phil., Librarian, Westminster College, Cambridge, and Professor Elisabeth Leedham-Green, Cambridge University Archives. I corresponded with Professor LeedhamGreen via Electronic Mail, and she very kindly directed my questions to the Reverend Mr. Houston.

38. Extract from the will of Stuart Johnson Reid, dated 28 March 1923, proved London 18 Nov. 1927.

39. Stuart J. Reid to Charles H. Gould, July 29th, 1895, MUA, Record Group 40, Libraries, Correspondence, Container 3, 1895 -.

40. Grace Redpath to Charles H, Gould, November 2nd, 1895 and January 25th, 1896, MUA, Record Group 40 Libraries, Correspondence, Container 3, 1895 - and 1896 -.

41. The Times (London) August 30, 1927.

42. Stuart J. Reid to Charles H. Gould, November 13th, 1901, MUA, Record Group 40 Libraries, Correspondence, $1901 \mathrm{M}-\mathrm{Z}$-.

43. The Times (London) August 30, 1927.

44. The confusion as to the profession of the collector of the Tracts is probably due to the fact that Sir J. William Dawson states in In Memoriam: Peter Redpath (op. cit.) that the Redpath Historical
Collection was "selected for him [Peter Redpath] by competent experts" (Dawson 8), a phrase that after time was transformed to "Librarian."

45. Stuart J. Reid to Charles H. Gould, July 29th, 1895, MUA, Record Group 40, Libraries, Correspondence, Container 3, 1895 -.

46. Grace Redpath to Charles H. Gould, January 25th, 1896, MUA, Record Group 40, Libraries, Correspondence, Container 3, 1896 - Q-R.

47. Stuart J. Reid to Charles H. Gould, September 18th, 1899. MUA, Record Group 40, Libraries, Correspondence, Container 4, 1899 - Mc-R.

48. Robert Bowes to Charles H. Gould, November 2nd, 1900, MUA, Record Group 40, Libraries, Correspondence, Container 4, 1900.

49. Library Letter Book, Volume 7, p. 533, MUA, Record Group 40, Libraries, Container 57, file 1598.

50. Stuart J. Reid to Charles H. Gould, November 2nd, 1900, MUA, Record Group 40, Libraries, Correspondence, Container 4, 1899 - Mc-R.

51. Library Letter Book, Volume 7, p. 597, MUA, Record Group 40, Libraries, Container 57, file 1598.

52. Stuart J. Reid to Charles H. Gould, November 13th, 1901, MUA, Record Group 40, Libraries, Correspondence, Container 4, $1901-\mathrm{M}-\mathrm{Z}$.

53. Catalogue of a Collection of Historical Tracts, 1561-1800 in DLXXXII Volumes, Collected and Annorated by Stuart J. Reid. The Gift of Mrs. Peter Redpath to the Redpath Library, McGill University, Montreal (London: Printed by the donor for private circulation, 1901)

54. Athenorum, Number 3874 (January 1902), 114.

55. For a discussion of Colby see Stanley Brice Frost, McGill University : For the Advancement of Learming. 2 vols. (Montreal : McGill-Queen's University Press, 1980-1984): vol 1: 31 .

56. Charles W. Colby memorandum, unaddressed, 
April 22nd, 1904. MUA, Record Group 2, Principal Peterson, Container, D-G.

57. Sir William Peterson was Principal from $1895-$ 1919.

58. Formerly Sir Donald Snith.

59. Stuart J. Reid to Charles H. Gould, November 13th, 1901, MUA, Record Group 40, Libraries, Correspondence, Container 4, 1901 - M-Z.

60. Charles W. Colby memorandum, unaddressed, April 22nd, 1904. MUA, Record Group 2, Principal Peterson, Container, D-G.

61. Proximity in an archive is hy no means conclusive evidence. Hovever, the Colby memorandum to Peterson would be badly misfiled to find its way into this file (D-G), unless there was some connection with the two documents.

62. Sir William Peterson admitted to Principal Fairhaim that "Your reference to Mrs. Redpath has of course great weight with me." Sir William Peterson to Principal Fairbairn, March 14, 1904. MUA, Record Group 2, Principal Peterson, Container, D-G. Reid received a D.C.L. from Durham in 1907. Gould wrote a letter to Reid in late 1907 stating, "My heartiest congratulations on the DCL from Durham, which you received in the Summer." Charles H. Gould to Stuart J. Reid, December 20, 1907, MUA, "Library Letter Book," Volume 12, Record Group 40, Libraries, Container 57, file 1603.

63. Department of Rare Books and Special Collections to J. N. Buchanan, June 5th, 1970, MUA, Record Group 40, Libraries, Area Libraries: Rare Book Department - Redpath Tracts, Container 161.

64. This assumption continues to be current, see Directory of Special Collections of Reseurch Value in Canadian Libraries (Ottawa: National Library of Canada/ Bibliothètheque nationale du Canada, 1992): $\mathrm{XX}$.

65. Elizabeth Lewis, Report, August 1st, 1966.
MUA. Record Group 40, Libraries, Area Libraries: Rare Bork Department - Redpath Tracts, Container 161. Emphaxis mine.

66. Student's Report, May 23rd, 1968, MUA. Record Group 40, Libraries, Area Libraries: Rare Book Department - Redpath Tracts. Container 159. Emphasis mine.

67. It seems that the Tracts were not loxked at individually. In the card catalogue for Series 2 there is an entry under Prynne, William for "A Collection of fifty-three political and ecclesiastical Tracts." Since the same wording is used in the Catalogue it would appear that the printed catalogues were used and the individual volumes of tracts were not consulted.

68. Dean S.B. Frost to Prof. D.F. Theall, Menorandum dated December 2nd, 1966, MUA, Record Groun 40, Libraries, Area Libraries: Rare Book Department - Redpath Tracts, Container 161.

69. Elizaheth Lewis to John Archer, Memorandum dated January 26, 1967, MUA, Record Group 40, Libraries, Area Libraries: Rare Book Departnent Redpath Tracts, Container 161.

70. John Archer to Elizabeth Lewis, Memorandum, dated February 6th, 1967.MUA, Record Group 40. Libraries, Area Libraries: Rare Book Department Redpath Tracts, Container 159.

71. Keith Crouch to Elizabeth Lewis, Memorandum dated July 13, 1970、 MUA, Record Group 40. Libraries, Area Libraries: Rare Book Department Redpath Tracts, Container 161.

72. Based on Special Collecrions List, p. 19, McGill University Archives, Record Group 40, Area Libraries: RBD - Redpath Tracts, Container 161: McGill University Libraries, Department of Rare Books and Special Collections, "Redpath Tracts," the predecessor to Inventory of Special Collections; and Directory of Special Collections of Research Value in Camadian Libraries (Ottawa: National Library of Canada/ Bibliothèque nationale du Canada. 1992), 51. The description is taken directly from this work, with the correction of Series 2 for Series 3 
pertaining to the William Prynne tracts. The holdings of McGill has not been established, and the reported "20090" pamphlets seems precise, yet conservative.

73. MUSE is McGill's Online Public Access Catalogue. 